\title{
Risk Management in Commercial Banks' Participating in Private Equity -Case Study Based on Silicon Valley Bank
}

\author{
Zhou $\mathrm{Li}^{1, \mathrm{a}}$, Mei Jing ${ }^{1, \mathrm{~b}}$, Sun Xiaoyu ${ }^{1, \mathrm{c}}$ \\ 1.Department of Economics, Beijing Technology and Business University, Beijing, China \\ a.Zhouli@btbu.edu.cnｂ. Aquarius1227@126.com
}

Keywords: commercial banks, private equity, risk management

\begin{abstract}
Private equity ${ }^{1}$ in China has developed rapidly in recent years and commercial banks widely participated in PE business in many ways to share the profits. The risk of loan affiliated to $\mathrm{PE}$ business and direct investment is far higher than that of the traditional business of commercial banks. Risk management becomes the key problem deciding whether China can allow mixed operation to give commercial banks the right to participate in PE. Silicon Valley Bank serve for startups and private equity firms for a long time, but it manage the risk successfully, with a low rate of Not-performing loan as $0.6 \%$. It has been one of the top twenty in the U.S. banks. Based on the study of Silicon Valley Bank, this paper compares and analyses risk-control problems which Chinese commercial Banks face, and put forward policy recommendations.
\end{abstract}

\section{Introduction}

Private equity, since introduced into China in 1980s, has been developed quickly and has been an indispensible part of capital market.

Since we step into 21 century, commercial banks in China has been developed fast. On one hand, we can see main banks go to IPO successively; on the other hand, commercial banks have made their transformation. PE's high payback has attracted commercial banks' attention already. But the participation of commercial banks in the private equity business is still stuck in the transition phase. As to commercial banks' direct equity investments, it is risk control that regulators care most. In the background of mixed operation in the U.S. for many years, Silicon Valley Bank has been cooperated with private institutions for many years. Its risk control and management is more mature. Study in Silicon Valley Bank case has important theoretical and practical significance for transformation of China's commercial banks and improvement of capital markets.

\section{Two main modes for domestic and foreign commercial banks' participation in PE}

According to different degrees of commercial banks' participation in private equity investments, the modes of participation of commercial banks in PE are divided into two categories the Leading investment mode and indirect mode of cooperation.

(1)Leading investment mode.

The leading investment mode refers to the commercial banks participating in direct private equity investment and loans in a leading role.

Law in China stated that the commercial banks in the territory of the People's Republic of China shall not engage in trust investment and securities operations, and not to invest in non-owner-occupied real estate or non-bank financial institutions and enterprises, except for there exist other rules.

China's commercial banks hope for mixed operation, but are under limitations of the regulations for now, so they make a reasonable interpretation of the provision to avoid the legal obstacles.

Engage in the private direct investment business through the establishment of subsidiaries abroad. "Commercial Bank Law" stipulates that commercial banks are not allowed to engage in investment business, this article refers to the territory of the People's Republic of China. But as to whether commercial banks' can invest in non-owner-occupied real estate, non-bank financial 
institutions and enterprises, this article did not impose restrictions.

Engage in the private direct investment business through the acquisition of trust companies. After a commercial bank's acquisition of trust company, the trust company acts as a trustee, accepts the trust and handles trust affairs conduct of operations. This helps the commercial banks to develop a way to be engaged in direct investment business.

Engage in the private direct investment business through other ways. The bank actually owns the stock options which are nominally held by private institutions, and receive income in the future to other name. For example, option loans.

Invest-loan-combination. Invest-loan-combination means that commercial banks provide loans to enterprises that have been invested by PE. In this way, banks can combine equity investment and bond investment. After PE's investment, commercial banks will provide loans according to the development of enterprises.

(2)Indirect mode of cooperation mode

Due to domestic legal obstacles of direct investment, the major commercial banks raise fierce competition in indirect cooperative business. Shanghai Pudong Development Bank has set up a sector on head office level to engage in direct equity investments, and carry out a comprehensive plan for PE service, which includes 7 sub-hierarchies: wisdom- provide plan for PE, finance-support the finance of $\mathrm{PE}$, investment- serve for $\mathrm{PE}$ investment, loan-plan for the combination of invest and providing loans, management-plan for the management after investment, quit-plan supporting quit afterwards, assurance-trusteeship service for PE. This series of plan can provide comprehensive service for industry chain.

Provide trusteeship service for PE. For most commercial banks in China, trusteeship business is the main business of the banks to participate in private equity investments.

Provide private intermediary services such as assessment, recommendation, consulting. Commercial bank to use its own reserves of commercial and financial information, provides a comprehensive corporate credit rating services and investigative services of due diligence reports for private equity investment institutions; With its extensive customer resources, commercial banks also recommend value-added services initiatively for private equity investment projects, and explore and establish potential investment project; commercial banks also provide investment advisory and investment assessment services, increasing intermediary business revenue and promoting transformation of business of commercial banks and innovation in financial services.

\section{Case study of Silicon Valley Bank}

\section{(1) General introduction of Silicon Valley Bank}

Silicon Valley Bank, founded in 1983, aimed at service Venture enterprises. In addition to its traditional banking business provided by Silicon Valley Bank, it also has established a venture capital fund directly involved in investment, and itself acts as a shareholder or partner of the venture capital firm. Silicon Valley Bank Venture Capital funds accounted for only $2 \%-3 \%$ of the investment, but greatly improve its overall profitability.

Silicon Valley Bank's customer orientation is very clear, that is venture capital supported and hasn't been listed high-tech small and middle enterprises (SMES).

(2) Business model of Silicon Valley Bank

High lending interest rate of loan. Silicon Valley Bank's major customers are just starting out scientific and technical enterprises, due to the high risk of such enterprises, Silicon Valley Bank lending interest rates to these customers are higher than other commercial banks. In addition to the high risk, the extensive network of resources of Silicon Valley Bank contributes to its high lending rate as well, with which Silicon Valley Bank is able to solve the follow-up financing problems and design financing options.

Bond investment and equity investment model. Silicon Valley Bank only lend to enterprises invested by private institutions, and Silicon Valley Bank Group own venture capital companies.

Design finance plan for customers. Silicon Valley Bank design different financial solutions according to the growth stage in which the enterprise is. 
(3) Risk management of Silicon Valley Bank

Hazard isolation. Silicon Valley Bank's risk isolation is referred as setting up a firewall, with the investment business and general business funds separated.

Deep investigation and follow-up tracing service. In addition to relying on private institutions to do due diligence on loans enterprises, Silicon Valley Bank will do a thorough investigation through a variety of ways. Silicon Valley Bank intervenes into the customer enterprise for a long time to understand the business information, provides financial services, and reduces business risk level.

Account limitation management. Silicon Valley Bank set the maximum amount of loan is \$ 50 million. For small and poor fluidity companies, Silicon Valley Bank can only provide a few million loans. Even to those PE backed and good fluidity enterprises, Silicon Valley Bank Group will still limit loans according to accounts receivable, and require the pledge of assets as well.

Intellectual property as pledge of assets. Start-up companies often do not have fixed assets can be pledged. In order to control risk, Silicon Valley Bank will adopt the way to use intellectual property rights as pledge of assets. With the gradual development of the enterprise, the pledge can be replaced by the accounts receivable.

\section{Study of risk management of commercial banks' participation in PE}

As to PE's investment in start-up small enterprise, level of risk management is relatively high. As a result, there inevitably exist some conflicts between low risk requirements and high risk management. It can be said that the risk management of commercial banks is now the most key problem determining whether our country can approve the mixed operation allowing commercial banks to participate in the equity investment. And it is also a determinant to whether commercial banks can be able to maintain steady and rapid development and improve the competitiveness in the equity investment business.

\section{(1) Conflict between security of funds and risk of investment}

Due to the different risk profile of the bank deposits in China and Silicon Valley Bank deposits, the foundation of invest-loan-combination business between China's commercial banks and Silicon Valley Bank is different.

In order to ensure the security of the deposits, China's commercial banks are risk-averse, the indifference curves of China's commercial banks are relatively steep, and they are more likely to choose a risk-free asset, loan, thus fewer loans to enterprises; Silicon Valley Bank, who is relatively risk appetite, has much more smooth indifference curves. This means Silicon Valley Bank is more biased in favor of select risk assets, even configure all risky assets.

So far, according to the banks' risk requirements and risk control level, China's banks lending loans to start-ups or direct equity participation is not conducive to control risk of commercial banks. A more reasonable approach is to combine investment and loans provision, and isolate funds between traditional lending business funds; and to separate funds of equity investment and funds of the traditional lending business. Funds of invest-loan-combination and funds of equity investment must be matched to risk preference of customers.

\section{(2) Cooperation between banks and PE with different properties}

Banks and private agencies cooperate and service for enterprises. Bank provides debt investments and PE provides equity investments. According to the experience of Silicon Valley Bank, the start-up stage companies are generally imposed higher lending rates. In general, private institutions and banks use different criteria of project selection, which is determined by their different properties. China Banking Act explicitly requires commercial banks to operate on the safety, effectiveness, mobility principle; and private equity funds pursue high-risk, low liquidity and high-yield. Being confronted with the high-risk groups of customers, banks' risk compensation will be far from enough without high loan interest rates. Therefore, the unmatched benefits and risks under current mechanism is not consistent with the laws of the market.

As to China's commercial banks' participation in private equity investment, equity investment should be open as a more effective means to control the Bank's overall risk.

(3) Regulation of commercial banks' participation in PE and corporation administration 
Since coming into the mixed operation, the United States, the regulatory system has also undergone changes. But the classification regulation in the United States is not in accordance with the financial institutions to classification, but classified in accordance with the "function" of the financial institution.

China has been in the implementation of separate management and separate supervision mode. This regulatory needed change in the context of bank gradually growing to mixed.Regulation can guard against systemic risk of banks, prompting the bank to a lot of internal problems are solved. Integrated operation within financial institutions, there is a conflict of interest and other potential risk incentives, so strict corporate governance structure is a necessary condition for effective control of risks.

\section{Advice for risk management of commercial banks’ participation in PE}

In addition to getting prepared for the opening equity investment in the future, the invest-loan-combination business of bank also requires banks to change concepts and systems of risk control.

Create firewall system. A firewall system must be created. Equity investment and the funds needed for the start-up investment-linked loan business must be separated with other loans funds.

Improve corporate governance structure. Corporate governance structure is mainly the construction of the internal control system. Supporting system construction is a very important part of the system. The system must have clear risk points and fulfill incompatible positions separation system.

Emphasize connections with PE and enterprises. Risk compensation may make up for the loss of the bank's risk, but is not conducive to the growth of bank risk control level and can not promote active lending. Banks and private institutions should establish strategic cooperative relations. Strengthen the cooperation with the private sectors can expand network of relationships. Cooperation between banks and private agencies also in line with the interests of both sides, the sharing of different advantages in resources can enhance the overall efficiency. It can be said that the construction of the network of relationships is beneficial to the bank's risk control, market position, reputation and revenues.In addition to the pre-control of risk, banks must keep in touch with enterprises afterwards to master the level of risk, provide value-added services for enterprises, introduce third-party investment, and make the risk under control.

China's private equity industry is now in a stage of rapid development, some banks, especially the joint-stock commercial banks are more mature in the private equity business. In the process of carrying out equity investment business, banks and regulators all should move forward carefully.

\section{References}

[1]Chen Guliang, Private market and commercial banks, West Papers, no. 6, 2008

[2]Gao Zhengping, Analysis of commercial banks’ PE business in China, Bankers, no.3, 2010

[3]Hu Tao, Exploration of modes in which commercial banks participate in PE, Economic Managers, no.15, 2011

[4]Wang Zhong and Bian Yingdan, Study of PE in the view of commercial banks, Finance Forum, no.10, 2008

[5]Xu Xiaoqian, Study of PE business of commercial banks, Entrepreneurs Home and Abroad, no.13, 2012

[6]Zhou Min and Fu Yan, Status of PE and strategy for commercial banks, AcademicJournal of Finance School of Shanghai, no.5, 2011 